\title{
The Portrait of Implementation of Antenatal Classes
}

\author{
Syamsulhuda Budi Musthofa ${ }^{1}$, Tri Joko Raharjo ${ }^{2}$, Dwi Yuwono Puji Sugiharto ${ }^{3}$, Achmad Rifai \\ $\mathrm{RC}^{4}$ \\ \{syamsulhuda@lecturer.undip.ac.id'1,trijokoraharjo@mail.unnes.ac.id², \\ dypsugiharto@mail.unnes.ac.id ${ }^{3}$, rifaipls@mail.unnes.ac.id $\left.{ }^{4}\right\}$
}

Public Health, Universitas Diponegoro ${ }^{1}$, Educational Management, Universitas Negeri Semarang ${ }^{2.3 .4}$

\begin{abstract}
The antenatal classes is a study group of pregnant women with gestational age between 4 weeks to 36 weeks with a maximum of 10 participants. The purpose of this study is to describe an overview of the implementation of antenatal classes based on information from the participants of antenatal classes, midwives, and health experts/academicians. This is quantitative research; questionnaires involved 206 respondents, in both city and district of Semarang, and informed consent was provided to the informants and signed it before interviewing them. By the program, the implementation of antenatal classes goes well as carried out by the Puskesmas (community health centers). By the fact, there were inappropriate methods in delivering materials of antenatal classes, the availability of facilities and infrastructure, and special facilities that should be provided for pregnant women and need to be considered and improved.
\end{abstract}

Keywords: antenatal classes, antenatal education, pregnant women.

\section{Introduction}

Maternal Mortality Rate (MMR) in Indonesia is one of the health problems which become a top priority to be resolved. Cause of maternal mortality in Indonesia was largely due to bleeding during childbirth, obstructed labor, sepsis, high blood pressure in pregnancy, and complications of unsafe abortion. Actually, most of causes of these deaths could have been prevented. In addition, the immediate cause of death can be inferred that the cause of maternal death is the result of three late, which is late in making a decision, late to be referred to hospitals/maternity center, and delayed getting health care services.

Making Pregnancy Safer (MPS) is an initiative launched by the World Health Organization in 2000. This is a commitment to reduce the global burden due to death, illness, and disability that can be avoid related complication during pregnancy, labor, and childbed/nifas. MPS strategy includes three key messages that every birth should be helped by trained health care worker/personnel/professionals, every complication during childbirth have to be addressed adequately by health care workers, and every woman of childbearing age should have access to prevention on pregnancy and treatment of complications of miscarriage.

The Indonesian government issued a policy for reducing maternal mortality with one of strategy is increasing the coverage and quality of maternal and newborn health care which cost-effective and supported by cooperation across programs and related sectors, other partners, public and private, women and family's empowerment and community empowerment. One of these real efforts of the policy by Develop Antenatal classes by 
utilizing Books of KIA (Maternal and Child Health), which facilitated by the local midwife, especially the primary health care midwife. Antenatal Classes are a means to learn about the health group for pregnant women, in the form of face-to-face which the aims are to improve the knowledge and skills of mothers about pregnancy, childbirth, postpartum care, and newborn care, through the practice of using the Maternal and Child Health book.

Currently, Antenatal Classes is something new, which is why there is a necessary need for socialization and training at the same time, especially for health cadres. Existing health cadres in posyandu (center for pre and postnatal health care and information for women and for children under five) is an important target in marketing antenatal classes because health cadres are people who first contact with women/mother (and couples of childbearing age) that exist in the local environment as well as having more closeness than other health care workers.

Access to prenatal care in health services is one important point in the effort to reduce maternal mortality. An effort to improve coverage of antenatal care is one strategy for reducing maternal mortality. This effort requires cross-sectoral cooperation, including increasing the active participation of health cadres and empowerment of women, family, and also community. One of the important activities and supported through government programs in order to decrease the maternal mortality rate is through the implementation of an antenatal classes, which aims to help improve the knowledge and skills of mothers about pregnancy, childbirth, postpartum care, and newborn care, through guided practice with the bookof KIA. Therefore, it is needed about the explanation and description of the happens of implementation of antenatal classes in the field.

\section{Methods}

This research is designed to describe the implementation of antenatal classes which so far have been carried out in various regions. The Semarang area is considered representative to describe the state of the implementation of the antenatal classes. The aim is to get a portrait picture of the implementation of this program during the antenatal classes..

This research is a quantitative study whose data are presented descriptively, obtained from 206 respondents who were former antenatal class participants who at the time of the study had babies. Data collected through interviews using a structured questionnaires in the research area that has been determined, that in cities and districts of Semarang. The data were then analyzed using descriptive percentages, to explain the facts as they are and describe the behavior of the participants.[1][2]

\section{Results and Discussion}

Semarang is a city with the second-largest maternal mortality rate from 35 cities/districts in Central Java with 32 cases (2016) which declined from 35 cases (2015), and most occurred in the puerperium period $(71.87 \%)$. The coverage of complications that opened increased rapidly from $58.1 \%$ (2015) to $129 \%$ (2016) from 5,963 estimated cases of complications that occurred. Most of the complications of pregnancy are pregnant women, hypertension, and complications of chronic diseases[3], [4]. Based on data from the Health Office, it is estimated that in 2017 , there are 28,758 pregnant women from 37 working areas in the health center in Semarang. 
As the basic of the study, quantitative data were collected on 206 women who had attended antenatal classes. Women domiciled in Semarang were 117 people and outside of Semarang 89 people. Their age is in the range of 16 to 45 years, with an average age of 28 years 4 months. Five of them were in the category of vulnerable in labor. Most of them $(83.5 \%)$ had parity below $2.67 .5 \%$ had a high school education, and only $16 \%$ were undergraduates. In employment status, there were $69.4 \%$ as housewives and $18.3 \%$ as civil servants and employees.

It turns out that all pregnant women have received a pink book of KIA even though not all of them were given the first pregnancy checkup (12.6\%). However, there were $1.5 \%$ of mothers who were unable to show the existence of the book of KIA when asked for the existence of the book because it was absent (missing, not stored properly). The most important thing of benefits obtained from the use of book of KIA are that the mother and child have a complete health record, from the time the mother begins to become pregnant until the child is five years old.[5] Material about pregnancy, care during pregnancy, and about childbirth are ranked highest as the knowledge needed by pregnant women. Most of what is desired by pregnant women in the teaching and learning process in the antenatal classes refer to reading materials and real examples and images either through films or visuals or artificial objects. More than half $(54.9 \%)$ consider that the process runs without any variation in the use of learning media. Many meeting places that are usually determined in planning meetings are chosen in public facilities or community meeting places next to public health services (puskesmas) or utilizing their own bidan houses.[6][7]

The husband's role in the Pregnancy Class $61.2 \%$ is limited to taking his wife to the meeting place, $85.9 \%$ have never listened to or followed the course of the antenatal classes, but strangely there were $28.6 \%$ of husbands from other pregnant women who were declared to take classes Pregnant mother. In carrying out antenatal classes, it turns out that midwives cannot be separated from the role of good cadres starting from preparing to assisting in the implementation of these activities, besides that they will certainly be helped by the role of PKK (Family Welfare Empowerment) mothers and village/village officials. The public understands that the activities of the antenatal classes are funded more by the government, and in the end, it will be supported by the existence of cash in the village and the PKK. So, the aspect of independence is low. In addition to midwives who are speakers in antenatal classes, there are also many requests to involve other puskesmas officers to become resource persons, even specialists.[8][9]

In carrying out the activities of antenatal classes as in the manual for the implementation of antenatal classes, midwives play a key role. In the field, the fact is inherently helped by the participation of PKK cadres and mothers as well as village/village officials and certain communities. In carrying out the activities of antenatal classes, in addition to midwives acting as the main resource persons, it turned out that in practice the officers of the puskesmas and specialist and general doctors involved, including community leaders.[10] This needs to be appreciated because empowerment and utilization of surrounding human resources can be utilized maximally (local wisdom).[11]

Learning media that are commonly used are still simple, impressive using existing facilities. But some have been able to use and utilize electronic facilities. In the implementation of antenatal classes, activities still need to be empowered to use interactive learning media. In the opportunity to read books of KIA that have been shared or received, only $23.2 \%$ of the total respondents read all of them from the book of KIA. And $28.4 \%$ said almost everything was read. This means that interest in reading and paying attention from pregnant women who participate in antenatal classes is still less than half. In carrying out the 
activities of antenatal classes as a matter of fact, more takes place in the place or hall of the community meeting or in the house of the mother of the midwife or the puskesmas. However, in certain regions where the place or house of a representative community is welcome to be used.[10][11]

The process of implementing antenatal classes turned out that $81.6 \%$ of participants stated that they were uncomfortable because feeling hot during the process of teaching and learning took place. So that sitting for long feels uncomfortable. Therefore it is necessary to pay attention to the issue of comfort (ergonomics) during the process. Facilities available during antenatal classes can be indicative of comfort indicators during the implementation of antenatal classes. $72.9 \%$ The implementation is still using mats, even $48.1 \%$ are not available bathrooms/toilets, but after being asked separately whether there is a bathroom/toilet available, it turns out $88.8 \%$ stated that they were available (see appendix statistics). The other side $81.6 \%$ of mothers feel enjoy it with these conditions. However, the implementation of the antenatal classes still needs to improve facilities, especially for the convenience of the process of transfer of knowledge from book of KIA materials.[10][12]

Nearly $90 \%$ there are no contributions collected to participants in the pregnant women class; after tracing, the contribution turns out to be voluntary or a contribution to help the activities of antenatal classes. Only one person pays antenatal classes because they are specifically administered in a hospital (not a government program). The material that has been given as long as memory is based on the respondent's answer is about the matter of pregnancy and complaints and treatments during pregnancy are the most remembered, as well as material about childbirth and childbirth and baby care. Regarding myths, infectious diseases, and the importance of birth certificates are rarely remembered by respondents. The material obtained by respondents who are mostly remembered is about the matter of pregnancy and complaints and treatments during pregnancy are the most remembered, as well as material about childbirth and childbirth and baby care. Regarding myths, infectious diseases, and the importance of birth certificates are less remembered.

Information about childbirth is a message that is needed by participants in antenatal classes as a basic need for information about how to deal with labor (74.7\%), in addition to information about pregnancy $(47.9 \%)$, postpartum care $(37.9 \%)$ and care for newborns $(36.8 \%)$. Health care officers (pediatricians and general practitioners and puskesmas officers) are the choices of respondents as appropriate figures to be used as resource persons in antenatal classes besides midwives. This shows that information related to antenatal classes must be provided by resource persons who are competent in their fields. Almost all respondents (91.3\%) said they were ready, but after further exploration, even though there were mothers who stated they were not ready at that time, thanks to their participation as participants in antenatal classes.

\section{Conclusion}

The program of antenatal classes has been going well and running as it should be following the instructions for implementing antenatal classes. This can be seen from the continuity of the implementation of the antenatal classes and support from the community and government as well as reports of activities at the Health Office. However, the quality of the implementation of antenatal classes needs improvement and improvement in terms of human 
resources that provide material and complete facilities for infrastructure facilities for antenatal classes. 


\section{References}

[1] J. W. Creswell, Research Design - Qualitative, Quantitative, \& Mixed Methods Approaches, vol. 4th Ed. Los Angeles: Sage, 2014.

[2] L. S. Musianto, "Perbedaan Pendekatan Kuantitatif Dengan Pendekatan Kualitatif Dalam Metode Penelitian,” J. Manaj. dan Wirausaha, vol. 4, no. 2, pp. 123-136, 2002.

[3] R. Kemenkes, Profil Kesehatan Indonesia Tahun 2016. Jakarta: Kementerian Kesehatan Republik Indonesia, 2018.

[4] Kementerian Kesehatan Republik Indonesia, Profil Kesehatan Indonesia 2018 [Indonesia Health Profile 2018]. Jakarta: Kementerian Kesehatan Republik Indonesia, 2019.

[5] C. Sistiarani, S. Nurhayayati, and Suratman, "Faktor Yang Mempengaruhi Peran Kader Dalam Penggunaan Buku Kesehatan Ibu dan Anak,” J. Kesehat. Masy., vol. 8, no. 2, pp. 37-43, 2013.

[6] A. Nurdiyan, Desmiwarti, and R. Machmud, "Analisis Sistem Pelaksanaan Kelas Ibu Hamil di Puskesmas Malalak dan Biaro Kabupaten Agam,” J. Kesehat. Andalas, vol. 4, no. 1, pp. 1-9, 2015.

[7] M. M. A. Almalik and S. M. Mosleh, "Pregnant Women: What Do They Need to Know During Pregnancy? A Descriptive Study,” Women and Birth, no. S1871519216301020--, pp. 1-7, 2017.

[8] R. Septiani, "Pengetahuan, Sikap Ibu Hamil dan Dukungan Suami dengan Keikutsertaan Ibu Hamil dalam Kelas Ibu Hamil di Puskesmas Kota Metro Lampung di Puskesmas Kota Metro Lampung,” J. Kesehat., vol. 4, no. 2, pp. 408-415, 2016.

[9] K. Kesi, "Analisis Fungsi Manajemen dalam Pelaksanaan Kelas Ibu Hamil di Puskesmas Bandarharjo Kota Semarang 2013," 2013.

[10] N. Fuada and B. Setyawati, "Pelaksanaan Kelas Ibu Hamil Di Indonesia," J. Kesehat. Reproduksi, vol. 6, no. 2, pp. 67-75, 2015.

[11] L. Hidayah, O. W. K. Handayani, and D. R. Indriyanti, "Pelayanan Kesehatan Maternal Dalam Akselerasi Penurunan Maternal Mortality," Public Heal. Perspect. J., vol. 1, no. 1, pp. 35-43, 2016.

[12] E. B. Sihsililya, Kuntoro, and B. Trijanto, "Keikutsertaan Kelas Ibu Hamil Berpengaruh terhadap Pengetahuan dan Sikap Ibu dalam Praktik Inisiasi Menyusu Dini Participation in Prenatal Class Affects Mothers 'Knowledge and Attitude in Early Breastfeeding Initiation," Obstet. Ginekol., vol. 24, no. 1, pp. 8-12, 2016. 